\title{
Identity Checks as a Professional Repertoire
}

Fabien Jobard and Jacques de Maillard

The longest and most striking spate of urban riots in France's contemporary history was sparked by a mere identity check. On 27 October 2005, three children ran from police who wanted to check their IDs, which they didn't happen to be carrying. Two of them never came back from the chase. They were electrocuted by a power transformer that they thought would make a good hideout. "Dead for no reason" said the banners at the many marches and demonstrations that followed, trying to convey the disarray sparked by the degree of brutality that the relationship between urban youth and the police had reached.

As a matter of fact, the youths certainly did not run away "for no reason" on that fateful night. ID checks often constitute an opportunity for aggressive behavior on the part of the police, especially towards youths from ethnic minorities - such as Zyed Benna and Bouna Traoré. Since the 1980s, the general public in France has become all too familiar with the phrase "contrôle au faciès." This term is the vernacular equivalent of "racial profiling" that sums up the main argument against this practice, namely its discretionary and discriminatory nature. That stop-and-search is often discriminatory and likely to generate dynamics of defiance has been amply demonstrated by research both in the USA (Paulhamus, Kane, Piquero, 2010) and in the UK (Bradford 2017). In France, while social movements began documenting this aspect of police work as early as the 1980 s, only in the 2000 s did research begin to produce enough quantitative evidence of the extent of the problem that this perennial concern reached the public agenda.

Three dimensions of the problem will be addressed here: describing what the checks are and who is targeted; showing why they are such a cardinal practice for the policing profession in France; and finally reviewing the many heated debates of the last few years to see whether practices have changed as a result - or not.

\section{ID Checks in France}

When towns - places where people unknown to each other coexist on a daily basis started developing in the nineteenth century, the police officer was a public agent whose mandate consisted, among other things, in asking passers-by about their social status. This was standard practice even before carrying an official identity card was required by Vichy France (Piazza and Laniel 2008). The tradition only recently found its way into legislation, specifically by way of the "Security and Liberties" law of 2 February 1981. This act gives a precise to definition "administrative" - or "preventive" - stops. They involve no offence or even suspicion thereof and are simply meant to prevent any breach of the peace or public order. These are controversial checks, as "public order" is a vague enough notion to make the domain of police intervention virtually boundless. They grant police colossal freedom when it comes to deciding what public order is or isn't, and monumental discretionary power in choosing to act (Foucault 1981; Napoli 2003).

ID checks are largely regulated by chapter 3 of the Code of Criminal Procedure (Code de procédure pénale, or CPP), i.e. articles 78-1 to 78-6 CPP, established by the law of 1981. Article 78-2 allows administrative or preventive stops whenever a police officer has "plausible cause" to suspect that a person has committed or is about to commit an offence (a 
rather unspecific formulation already). However, persons might also, and "regardless of their behavior," be stopped to prevent a breach of public order or security. These labels obviously cover an immense realm of possible activities. Preventive stops may also be requested by the public prosecutor for a specific area and time period. There, the police nationale and gendarmes can perform stops regardless of people's behavior, for the purpose of uncovering explicitly mentioned violations or offences. It is often the case that the offences listed in the public prosecutor's order cover a broad range of possible street offenses, including breaches of immigration laws, which conveniently makes it possible to stop and check just about anyone, and especially anyone appearing to be foreign. These criteria are how most preventive stops are legally justified.

In 1993, the Constitutional Council, whose role consists in ensuring that new legislation is consistent with the French constitution, established that "the practice of sweeping, discretionary ID checks is incompatible with respect for individual freedom" (DC 93-323). In 2017, the Council pointed out that "ID checks must be implemented [...] exclusively on the basis of criteria that are untinged by discrimination of any kind" (2016606/607). An earlier decision by the Court of Cassation (France's top civil and criminal court) had already established that the elements used to justify a stop must have nothing to do with who the person stopped is. In particular, their outward appearance - for instance the fact that they look foreign - does not constitute a valid motive for a stop (Ruling, Court of Cassation, 23 April 1985).

However, one peculiarity of the French ID check is that it generates no administrative record. Persons who are stopped are is not issued any receipt from the police, and they in turn do not record the stop in any way unless contraband is are found. ID checks leave no trace. What did the Constitutional Council prescribe in 1993 when it posited that ID checks may not be "discretionary"? What concrete measures were contemplated? The Council left these questions up to judges in cases in which a stop is challenged. Then the officer responsible for it must be able to justify it in court. The Constitutional Council could have nullified the bill on the grounds that the police were being granted disproportionate powers, but it did not. As a result, French police officers may check the legality of anyone's status at will, these checks leave no paper trail, and potential claimants - unless they can produce half a dozen reliable witnesses - have no material evidence to support their claims in front of judges, who are the only ones who may protect their rights.

\section{Litigation by the Open Justice Initiative}

To challenge the potentially discriminatory consequences of this stop-and-frisk policy, a collective supported by discrimination lawyers and the Open Justice Initiative (OSJI) has brought 13 ID-check cases to the civil courts (Hollo and Bobis 2013). Their claim was that these were not criminal but civil cases, a legal strategy that is much more common in the United States than it is in France. Civil cases may draw upon non-discrimination laws, which largely rest upon European Union legislation that tends to reverse the burden of proof: it is up to the defendant (in this case, the French state) to prove that there was no intention to discriminate against someone who happened to be Black or Arab and has been stopped on the street for no apparent reason.

While the tribunal top which these cases were assigned summarily dismissed all thirteen cases (Sayare 2013), two years later the Court of Appeal found unlawful discrimination had been exercised in eight of them. The court rules that the French state had 
failed to justify the stops made by the police officers and, more specifically, to ensure that checks were based on objective grounds rather than based on race or ethnicity. The state appealed to the Court of Cassation, which a few month later confirmed the dismissal of five of the thirteen claimants (more on this later) and the fact that eight stops were unlawful (Ruling, Court of Cassation, 9 November 2016). Moreover, the Court of Cassation stated (contrary to the argument of the state) that non-discrimination law does apply to police stops. This implied a shifting of the burden of proof to the state and opens further opportunities for potential claimants to seize the initiative. It is now the state's responsibility to prove that a given stop was not founded on a discriminatory decision, if the claimant is able to provide some evidence of the non-objective character of the stop (Dumortier 2015).

Still, concluding that French law has become aligned with American law in this matter would be a stretch. While the Court did quote statistical data suggesting that some forms of police discrimination do exist -- including Jobard et al. 2012 -- these data are treated as illustrative rather than evidentiary. Furthermore, witness statements from reliable, neutral third parties are still required. However, in many circumstances (stops performed at night, or in neighborhoods few outsiders ever transit), these are simply impossible to provide. Finally - and this had a direct impact on the five claimants who were dismissed - the Court argued that in areas "notoriously affected by crime," preventive stops may be allowed. At the end of the day, the requirement of neutral, impartial third-party witnesses on the one hand, and the creation of special territorial exceptions on the other, mean that opportunities for turning to the courts will be few. This is especially true as far as one specific category of people is concerned, youths (often from ethnic minorities) who live in the banlieues (suburbs) of major French cities and tend to be stopped either in their own neighborhood or in highly-surveilled areas such as railway stations. Thus, in 2016 the Court of Cassation rendered a double-sided ruling. On the one hand, it acknowledged that ID checks may be regulated under nondiscrimination law. Also, there was no requirement that a formal complaint had been filed, which was in itself a minor revolution. On the other, the Court concluded that urban areas where policing is already the most discriminatory can be territories that continue to justify preventive police stops. In doing so, the Court asserted a general non-discrimination principle while at the same time establishing that police action can be territorially - and therefore racially and socially - differentiated: law-compliant here, discriminatory there.

\section{Targeted Populations: Appearance, Gender and Lifestyle}

Over the last few years, studies have been conducted that shed some light on the populations that are targeted by ID checks. As noted earlier, no official records are kept on stops, and as a result, there is no such thing as useful police data. Therefore, the only way to examine targeted populations is to collect independent data, either through observational studies (the least frequent method) or surveys.

A study conducted in Paris in 2007-2008 by Fabien Jobard, René Lévy and John Lamberth (2012) was the first ever standardized observational study of ID checks. Five characteristics were recorded by the observers stationed in major Paris transit hubs: gender; age (young, older); race (White, Black, North-African, Asian, other); carrying a bag (no bag, bag, big bag); clothes (youth culture, business, casual). These data were collected for 38,000 individuals and compared with the characteristics of the subjects of 525 checks by police that observed at the same locations (see Waddington, Stenson et Don 2004 for a similar method). Ethnic minorities were found to be vastly over-represented. All other things being equal, the likelihood of being stopped was boosted by a factor of 3.2 to 9.1 for Black people, and 3.6 to 
14.5 for North-Africans. Other factors highly predictive of a stop included: being a male; being young; not carrying a bag; and wearing clothes identified with "youth culture." Since these variables are mutually correlated - for instance, two-thirds of "youth culture" individuals are Black or North African - determining the exact, independent weight of each variable is a delicate exercise. For example, there is no difference in the likelihood of being stopped between "casually dressed non-white young men" and "youth-culture young white men."

\section{TABLE 1 GOES HERE; TABLE IS IN A SEPARATE FILE BEGINNING Ch16...}

The magnitude of these differences can be seen in Table 1. It examines young men of all ethnicities who were wearing typical youth culture clothing and not carrying a bag. The top panel of Table 1 describes the frequency of such individuals in the universe of travelers observed in six different observation points. They always constituted a small fraction of those passing through these stations. The bottom panel reports the distribution of similar persons who were stopped in the same locations. They usually constituted a substantial proportion of all individuals who were observed to have been stopped.

Other studies of persons targeted by stops have on surveys. A survey carried out in 2009 by Beauchemin, Hamel and Simon. (2018) involved 22,000 respondents, three-fourth of whom had been racialized. Another carried out in 2016 by the French Ombudsman (Défenseur des droits) included 5,117 respondents and same ratio of racialized people (Défenseur 2017a). Both studies found that minority populations did not differ from the majority in terms of their likelihood of being stopped. Rather, what does set White respondents apart was their smaller risk of experiencing multiple stops. Beauchemin, Hamel and Simon study, $13 \%$ of majority-population respondents recalled being stopped several times over the past year, as contrasted to more than $20 \%$ of North-African or Turkish secondgeneration respondents, and $27 \%$ among second-generation respondents of African origin. In the Ombudsman's survey, although $23 \%$ of male respondents said they had been stopped at least once over the past five years, Black and "Arab" males were six to eleven times as targeted frequently, defined as being stopped more than five times over the past five years.

A survey study carried out with students from the greater Paris area also found nonsignificant difference between Whites and non-Whites in their likelihood of having been stopped at some point over the past year. Again, however, these contrasts were stronger when it came to multiple stops (56\% for non-Whites, compared to $41 \%$ for Whites) (Jounin et al. 2015). This study highlighted the predictive role played by descriptive and behavioral characteristics of respondents. How they dressed was the key: $76 \%$ of those wearing a cap reported having been stopped, versus $42 \%$ among those who did not wear one. The difference between hood wearers and non-wearers was also large, $53 \%$ versus $42 \%$. Non-Whites were more likely to fall into the cap and hood-wearing categories. An interesting point is that behavioral characteristics seem to counterbalance these effects. White students tend to be found in public spaces, especially festive ones, a lot more often than non-Whites, and as a result, are more exposed to stop-and-search. In addition, they are more likely to be found in possession of cannabis in the public space. A look at gender, clothing, and lifestyle variables further indicates that non-White males are, all other things being equal, the category most targeted by police stops [Jounin et al. 2015].

These findings were corroborated by the "Escapad" survey (Peaucellier et al. 2016) involving 5,432 18-year-old Paris residents. The study found a high frequency of stops among youths (28\% recalled they had been stopped), again with significant differences in 
stop rates among various social groups ( $41 \%$ of males, $47 \%$ of school dropouts, and $18 \%$ of residents from underprivileged areas). It also highlighted the importance of behavioral variables. Two-thirds of those who had been involved in a brawl reported being stop during the past year, as well as three-fourths of regular cannabis users. A multivariate statistical analysis revealed that the over-stopped group is made up of two distinct sub-groups. One group was dubbed "Epicureans." They made up 20\% of the total sample and consisted of upper-class youths who tend to go out often and consume cannabis and alcohol in much greater amounts than other youths their age. The second high-stop group were "recluses from poorer neighborhoods." They constituted $10 \%$ of the total sample, and they tended to live in rough areas, have few friends, to usually do not consume any alcohol or cannabis, and rarely go out.

In sum, discriminatory practices do not hinge exclusively on racial characteristics. While race can be said to be a predictive variable indeed, all other things being equal, it is certainly not the only relevant feature. Far from it - being a young male is strongly determining as well. However, race seems to be highly predictive as far as repeat stops are concerned, and it often overlaps other risk factors.

\section{The ID Check Process}

A police stop may involve only a simple ID check, but also can escalate into a fullblown frisk or search. So-called "safety measures" may occasionally be taken, such as requesting individuals to lean against a wall, placing their feet apart, with their back turned to the police and others who may be present. The Ombudsman's study (Défenseur 2017a) offers invaluable information on this aspect of stops. It found that males were 1.5 times more likely to be searched than females, for instance. The same goes for 18-24-year-olds versus 25-44year-olds. The risk of being searched redoubles for males who are perceived as Arab or North-African, contrasted to all other males. A full $80 \%$ of young males perceived as Black or Arab reported having been searched at least once, versus vs $28 \%$ of young males not in that category.

Regarding interactions with the police, studies find great variety in how people are handled by the police. In general, stops tend to be performed courteously, but the targets of stop rarely receive an explanation of why they were stopped. In the observational study conducted in Parisian transit hubs (Jobard and Lévy 2010), three-fourths of the 175 respondents surveyed immediately after having been stopped, reported that the officers had been "neutral" in their demeanor, while $6 \%$ considered the police to be "polite" or "respectful". The Ombudsman's and Jounin studies yielded similar results. At the other end of the spectrum, the Ombudsman's study noted that $8 \%$ of persons stopped reported having been treated brutally during the encounter, $7 \%$ said they had been insulted, and $16 \%$ were addressed by the familiar pronoun " $t u$ " rather than the polite "vous." Among males from minorities, these figures are much higher: respectively $24 \%, 29 \%$, and $32 \%$. In the Jounin study however (which is restricted to a youth sample), race was not a predictor of brutality, but gender and clothing were. Police "brutality" here does not involve (barring some rare exceptions) the use or threatened use of firearms, as opposed to what can happen in the USA (e.g. Skogan 2018), but rather shoving, pressure, and occasionally blows.

The Polis survey, carried out with German and French high school students, makes it possible to compare the respective actions of French and German forces. The German police 
were reported to give reasons for making stops in $66 \%$ of cases involving native Germans and $58 \%$ for youths of Turkish origin. Their French colleagues gave reasons for making stops to $54 \%$ of natives and about $44 \%$ of youths of North-African origin (Oberwittler \& Roché 2018).

\section{The Consequences of ID Checks}

The Ombudsman's survey concurred with other international studies (see for instance Bradford 2017, Epp, Maynard-Moody and Haider-Markel, 2014, Skogan 2018) in finding that stops, especially when lacking justification, are associated with a loss of confidence in the force. In that French study, slightly more than half those who reported having been stopped more than five times over the last five years did not trust the police, contrasted to $18 \%$ in the population as a whole.

An aspect of ID checks that differs along social lines is that of the perceptions generated among those who are stopped. In the observational study of persons who had just been stopped, Jobard \& Lévy (2010) noted that a vast majority of checks had been considered "neutral, respectful, or polite." But at the same time, $23 \%$ of North-Africans and $36 \%$ of Blacks reported they were "annoyed" or even "very upset" to have been stopped a few minutes earlier. Their rate of annoyance or upset was respectively 1.5 and 2 times higher than that among Whites (15\%). Working on the Beauchemin, Hamel and Simon (2018) data, Mélanie Terrasse (2019) focused on the consequences of stops on self-perception. In this survey, $93 \%$ to $97 \%$ of migrants born in France said they perceived themselves as being French, but only $63 \%$ to $78 \%$ of them reported being perceived as French by others. Once the effects of age, occupation, education, and neighborhood were controlled for, multiple (two or more) stops appeared to have a significant (though moderate) impact on how people think they are perceived $-15 \%$ to $-20 \%$, depending on the groups. In the Ombudsman's study, $46 \%$ of respondents who said they had been stopped more than five times over the last five years thought that French citizens are not equal before the law.

In a country such as France that holds citizenship sacred, the topic of police stops can be an emotional one. The process involves checking one's national identity card, which is their statement of citizenship. The ID check is an intensely political gesture for the large proportion of persons stopped who belong to ethnic minorities. They end up losing confidence in the police, they are further persuaded that they are not being perceived as French, and they are more likely than others to be convinced that seeking reparation and justice for unfair stops would be pointless.

\section{ID Checks as a Professional Repertoire}

These studies have yielded valuable information regarding the distribution, conduct, and consequences of ID checks. In practice, the legal framework surrounding them is vague enough to permit an extremely wide array of professional practices, which we will now examine in more detail. We then turn to the selection of target populations and conclude by exploring the paradoxical organizational "invisibility" of ID checks.

In practice, how do police officers exercise their discretionary powers? To determine this, we conducted a direct observation study of police officers to understand what contexts prompt them to take the initiative in making preventive stops (Maillard et al. 2018). It appears that the decision to perform a stop is typically motivated not by the behavior of those 
concerned, but by entirely different criteria. These include a belief that an individual does not seem to belong to the context, the outward appearance of their vehicle, how they are dressed, and their apparent attitude (as shown by a defiant, sideways glance for example). Our study was carried out in two provincial French towns, and it revealed that more than one in four interactions were discretionary stops initiated by the police. Overall, out of 293 interactions that we observed in the field, 80 featured a stop whose justification we could not find in the behavior of the concerned individual). These percentages differed considerably from those we observed in Germany. Like France (but unlike the United Kingdom), Germany does not systematically document stops, and does not keep statistics on the race of those involved in them. ${ }^{1}$ There, however, only 31 stops out of 247 that we observed appeared unjustified.

In France, ID checks are seen as a valuable and, one might say, routine tool for proactively identifying potential offenses. Although an otherwise unmalicious attitude or sustained gaze may not commonly signal any offensive behavior, to the police this might suggest that there is something suspicious going on. Officers can see themselves possessing a personal "flair" for spotting potential troublemakers and may stretch their understanding of the reasonable suspicion that is supposed to guide their decisions to stop people. Besides, since stops largely focus on finding drugs, especially in disadvantaged suburban areas (France is the number one country in Europe for cannabis consumption), ID checks provide an opportunity for searching people and recovering knives or banned substances.

Discretionary stops are also used as a device for asserting police power over housing estate youths. This works along three distinct axes: maintaining a visible presence, instilling respect, and dispensing street justice. When it comes to maintaining their presence, ID checks are a way for the police to take over the area and show the youths "who's boss." Stops perpetuate a relationship of dominance over their "customers" - people who Lee (1981) refers to as "police property" - by reminding them daily that police coercive powers may be exercised against them at will. Stops are usually performed despite the lack of any real security, investigatory, or true identification imperative, and often are imposed on individuals who are perfectly well-known to the officers. In 2013, local associations called upon the Open Society Justice Initiative to raise public awareness on the case of fifteen-year-olds against whom the police had been ordered to intervene by way of repeated, humiliating, aggressive stops (Boutros 2020). As the area was in the throes of gentrification, these youths (dubbed "unwelcome" in police documents) were expected to "buzz off". The Open Society Justice Initiative's investigation has revealed that the - totally unjustified - stops often gave rise to sexual assaults (batons in trousers, pat-downs of buttocks and testicles, etc.). The ensuing outcry created an opportunity for grown-up men to testify about practices they had been subjected to throughout their childhood.

Stops may also serve the function of commanding respect in situations of defiance or even provocation from the youths. As opposed to the previous case, checks are not routine here, but a response to some specific behaviors perceived as disrespectful. Whereas the bodies of earlier targets were considered "police property" as defined by Lee, in this instance they are "assholes," as described by Van Maanen (1978). One officers we interviewed had this explanation to offer for these stops: "The goal is to command respect, to show we're not afraid

1 In that regard, the idea - often mentioned by American colleagues - that the problem with France lies in the lack of ethnic statistics is simply delusional: in fact, other than the UK, not a single Western European country maintains such statistics. 
of them, you can't let them get away with anything. Then they realize that as long as they leave us alone, we leave them alone too!"

Finally, the last situation can be described as using ID checks as a sanction. Stops can involve a degree of public humiliation, including being forced to lean with one's hands against a wall for several minutes, subjected to a number of questions, or being frisked, all on the street and perhaps in broad daylight." These sanctions are a form of "street justice," which has been described as an important element of routine of policing (Skolnick 1966). Street sanctions can be a fallback when the police lack the evidence to arrest or bring charges against suspects, or when the matter is not serious enough to warrant prosecution. In this type of situation, which was observed in France but not in our German study, stops taken on a "disciplinary rationale" (rationalité disciplinaire, Gauthier 2015) destined to tame those who do not abide by the requirements of the police.

One striking feature of our observations and interviews is that the police consider ID checks as particularly beneficial in terms of their work on the field. They are a mechanism for collecting information, arresting suspects, and asserting their authority. The downsides of stops (such as the public defiance induced by repeat stops) are typically ignored, although this need to be qualified, depending on both the officers and the units involved. In the aforementioned research carried out in two provincial French towns, four different types of units were observed. This revealed variations in stop routines that were dependent on both the objectives and the methodology of stops (Maillard and Zagrodzki 2017). Plainclothes units tended to rely on them only marginally, whereas other units focus entirely on "police property." The variations we noticed may derive either from a given squad's remit, whether they work plainclothes or in uniform, the type and extent of their jurisdiction, or the watch commander's leadership style. In some stop situations, patrol leaders who interacted courteously with the public proved unable to keep their subordinates' aggressiveness in check. Ever since the tenure of Nicolas Sarkozy as minister of the Interior in the 2000s, aggressive units tasked with "taking over" and "reconquering territory" (the official terminology of public authorities) have been thriving, resulting in a legitimization of repeat, aggressive, humiliating police stops (de Maillard and Mouhanna 2016).

\section{The Logics Governing Target Selection}

It is well known that stops are prompted by proactive cues, based on "'shared-recipe' police knowledge about whom to stop for what purpose in particular circumstances" (Ericson, 1982, p. 86). As elsewhere, the French police act on the basis of "unexamined, implicit and subconscious stereotypes, biases and cultural assumptions" (Bradford 2017, p. 83). Maillard et al. (2018), and Gauthier (2015), writing on France, have noted that police classification logics have a complex way of combining dress, behavioral, geographical, and ethnic-racial elements. While no single variable is determining per se, many officers do subscribe to the following syllogism: minority youths are more likely to be delinquents, therefore stopping them is the rational thing to do (this applies in England too; see Quinton 2015).

The immediate context of the situation is also highly relevant. The likelihood that stops may be used in discretionary and humiliating fashion is fueled both by a general feeling of hostility towards the banlieues and ongoing tensions with the descendants of immigrants from former French colonies (see among others Jobard 2006, Fassin 2013). Although police officers take refuge behind the code of criminal procedure ("we are merely enforcing the 
law"), these stops are perceived by ethnic minority youths as part of a de-individuation scheme that tends to assign them to racialized groups (Zauberman and Lévy 2003) and negate their full citizenship (Blanchard 2014).

To policing scholars, these findings will not come as a surprise. Police officers have a wide-ranging conception of suspicion, and exercise implicit bias based on physical and cultural appearance. Such factors reign supreme when it comes to deciding to stop someone. This has been noted elsewhere, in Britain (Delsol and Skinner 2015) and the United States Epp, Maynard-Moody and Haider-Markel, 2014). Less frequent, however, is paucity of police data that can be used to monitor stops.

It appears that $\mathrm{D}$ checks seldom require follow-up action. Based on according the scattered measurement available, targets of stops are taken to police stations in less than $15 \%$ of cases. Both the police nationale and the gendarmerie make these estimates sporadically, and they report very low figures. In 1993, the police nationale claimed that $3.6 \%$ of stops led to arrests, and 25 years later, a gendarmerie estimate was a 4\% arrest rate (Marc 2016, p.15). Other than that, the authorities have no administrative tracking of the number of stops and how they are distributed, either among agents and units, or in space and time. Most ID checks are invisible within the police organization itself. The hierarchy does not receive reports about them. In 2014, upon special request from the Parliament, the gendarmerie estimated that $1.5 \mathrm{~m}$ people had been stopped by their agents at some point, but they counted only the stops that were at the request of public prosecutors! (Marc 2016, p.16).

This lack of transparency hampers any attempt to rationally draw up public policies aiming to regulate, monitor, or guide the use of ID checks. Not that elected representatives seem to be concerned about this. Although a 2016 report from the Senate's Law Commission mentioned that "the Ministry of Interior indicated that no overall statistics were available...", the curiosity of French MPs was not piqued (Marc 2016, p.16).

\section{ID Checks as a Political Issue}

Racial profiling is mainly referred to in France using the expression "contrôles au faciès." This term can be perceived both as a statement of fact and as a call for protest. The phrase has been in use ever since the 1980s, when second-generation immigrants first started to raise their voices regarding police conduct. The study by Jobard et al. (2012), published in June 2009, provided the first systematic figures ever on stops, and the data were considered at the time as "scientifically indisputable" by the Paris police spokesperson himself (Incyian 2009). A craze of "stactivism" (using statistics for activist means) then seized the nation, as a number of groups and political figures tried to leverage these data to further their own causes (Didier 2018). Interestingly, while statistics are usually perceived as a tool for state control, in this case demands for data resulted from the engagement of many actors who, despite being in a weak position, were hoping to strengthen their case against the state (see more generally Porter 1995).

This had a twofold effect. The first was, an agenda-setting one. Presidential candidate François Hollande, who won election in 2012, promised to fight racial profiling by pushing legislation for "a procedure [that would be] mindful of civil rights." This was universally interpreted at the time as a commitment to introduce a mandatory ethnic monitoring scheme like the one UK forces have been abiding by since 1996 (de Schutter and Ringelheim 2008, 379). This measure never saw the light of day (see below). The second, more long-term effect 
has to do with framing public debate. The lack of any quantitative data on stops has long acted as an enabler of the rhetoric of denial (Satzewich and Shaffir 2009). In fact, police have gone so far as to sue those who dared suggest that discretionary ID checks even existed (Incyian 2009). After 2009, police chiefs and union leaders were relentlessly asked the same question: "everybody knows that police stops are discriminatory; what do you intend to do about it now?" (Jobard and Lévy 2011). The most convincing outcome of research is that the cost of denial has surged dramatically.

A judicial front was also opened, largely supported by the Open Society Justice Initiative - the foundation that had funded the Jobard and Lévy study (Hollo, Neild 2012). This battle was fought in civil courts and culminated in the above-mentioned 2016 ruling by the Court of Cassation. Alongside the judicial battle, the Justice Initiative pressed a legal empowerment strategy fostering the development of leaders from ethnic minorities to champion their cause in France. This resulted, for example, in the creation in 2011 of the "Stop le contrôle au faciès" collective. Their initiatives included collecting testimonies, posting online videos, and involving rappers and football stars, were supported by the OSJI. ${ }^{2}$ The collective gradually joined the rally against discrimination and police brutality, and in support of youths from deprived French banlieues. The arbitrariness of police stops ended up being leveraged to cement a cause around which racialized youths may unite.

On 1 June 2012, a few weeks into François Hollande's first and only Presidential term, his Prime Minister announced that the Minister of the Interior was to spend the summer working on introducing the "récépissé," i.e. a receipt issued to stopped individuals in order to avoid racial profiling, and minimize repeat stops. By mid-August, the minister announced that the measure would not be implemented, citing the riots that were taking place at the time in the city of Amiens. He announced, "Can you imagine police officers handing out receipts tonight in Amiens?" (14 August 2012, France 2 broadcast). Minister of the Interior Manuel Valls, whose approval rating surpassed that of the Prime Minister, thus demonstrated how influential he was in the cabinet - until he took over as Prime Minister a few years later. Police unions voiced their discontent regarding the planned récépissé as early as June 2012. One proclaimed, "The public/police rift will not be bridged by making police officers feel the fault is theirs" (SGP trade union, 1 June 2012). They pledged to support the Minister of the Interior in return for the plan being dropped.

Faced with relentless political and activist pressure, though, the minister introduced two replacement measures that had the potential to significantly impact police practices. The first, revealed in December 2013, was to send messages of trust to the population and consisted in requiring a compulsory police collar number (matricule) that was to be worn at all times, even by plainclothes officers. This was actually a reversion to older practice. The requirement that a similar number be worn had been dropped at some point during the 1980s, though no one claimed to know when or how (Béguin 2012). A few years later, the Ombudsman (Défenseur des droits 2017b, p.47, also Sénécat 2016) pointed out that the collar number was in fact rarely worn by the police, and in 2019, it appeared during the "Yellow Jackets" protests that many instances of police brutality could not be brought to court because identifying police officers proved impossible! The second measure was introduced by a ministerial order of 25 April 2017. It requires police officers to use body-worn cameras in specific high-security urban areas (zones de sécurité prioritaire, or ZSP). Although these

2 See http://stoplecontroleaufacies.fr 
cameras may in principle be triggered at will by the police, they must be in use during an ID check.

Although the effects of these measures are hard to assess for the moment, it should be noted that in the context of French policing, the ID check is and remains a totem of sorts: there seems to be no risk that it will be uprooted, and it is not clear how effectively it can be amended.

\section{Conclusion}

ID checks are one of the central, and almost definitional, practices of French policing. Not only are they much more frequent than in most other Western European countries (FRA 2010), but studies have consistently shown that they lead to very numerous discriminatory practices, and that have more to do with asserting order maintenance than advancing peacekeeping. These checks have been in the spotlight for a dozen years or more, owing in particular to the efforts of the Open Justice Initiative. They have both funded research on the effective practices of police officers and contributed to empowering nonprofit organizations by mobilizing the media and political parties around the issue. They have also brought cases before the courts, up to and including the Court of Cassation. In this respect, police forces are currently experiencing levels of pressure that were unknown to them a mere fifteen years ago. Does that mean that practices are changing? They are not, or only quite marginally. The relevant legislation governing stops remains unamended, and the Court of Cassation has reminded everyone that there are indeed in France territories and circumstances that do justify police officers stopping whoever they like. Another aspect to this debate is terrorism. The spectre of terrorism has undermined some of the measures that had been taken in response to the debate on ID checks, including new requirements for body-worn cameras and collar numbers.

At the end of the day, discussions over the last decade about ID checks has highlighted several important political features of French policing. The first is the highly centralized nature of policing. Politically, this has turned policing questions into a card to be played on the national political stage. Thus our emphasis on the political ambitions of Ministers of the Interior and the role played by Presidential administrations in police policy. The tenures of both Nicolas Sarkozy (2002-2004, then 2005-2007) and Manuel Valls (20122014) have been symptomatic. Second, the debate has revealed the weight of police unions. In contrast to nations in which policing is the responsibility of local government, in France police unions can aim their proposals and protests at one target, namely the Minister of the Interior. A reform may be ditched for the sole reason that powerful unions do not agree with them. Even legislation they are unable to prevent can still be killed in practice; witness collar numbers. Third, civil society, which when it manages to get organized (as it did concerning ID checks) still has the power to at least add items to the political agenda, and draw support from strong institutions (such as the Ombudsman or political parties). The impasse that political factors have created for reform efforts in France have by-and-large insulated ID checks and related practices from actual change. This has led to an overall increase in political tension around these issues and has added to the urgency of tackling them head on.

\section{References}

Beauchemin, C, Hamel, C., Simon, P. 2018. Trajectories and origins: Survey on the diversity of the French population. Frankfurt: Springer. 
Béguin, F. 2012. Le grand retour du matricule dans la police. Le Monde, 17 octobre.

Boutros, M. 2020. PhD Dissertation. Evanston, Illinois: Northwestern University, Department of Sociology.

Bradford, B. 2017, Stop and search and police legitimacy. Abingdon: Routledge.

Défenseur des droits. 2017. Enquête sur l'accès aux droits, vol. 1. Paris: Défenseur des droits.

Défenseur des droits. 2017b. Le maintien de l'ordre au regard des règles de déontologie. Paris: Défenseur des droits.

Delsol, R. and Shiner M. (Eds.). 2015, Stop and search. The anatomy of a police power. Basingstoke: Palgrave.

Didier, E. 2018. Globalization of quantitative policing: Between management and statactivism. Annual Review of Sociology 44: 515-534.

Dumortier, T. 2015. Les 'contrôles au faciès' saisis par la justice. Revue des droits de l'homme, Actualités Droits-Libertés.

Epp, C., Maynard-Moody, S. and Haider-Markel, D. 2014. Pulled over. Chicago: University of Chicago Press.

Ericson, R. 1982 Reproducing order: A study of police patrol work. Toronto: University of Toronto Press.

Fassin D., 2013, Enforcing Order. An Ethnography of Urban Policing. Cambridge: Polity.

Foucault, M. 1981. Omnes et singulatim. Towards a criticism of political reason. Pp. 223-254 in S. McMurrin (ed.) The Tanner Lectures on Human Values. Salt Lake City: The University of Utah Press.

FRA (Fundamental Rights Agency). 2010. EU-MIDIS: Main results report. Luxemburg: Publications Office of the European Union.

Gauthier J. 2015. Origines contrôlées: Polices et minorités en France et en Allemagne. Sociétés contemporaines 97: 101-127

Hollo, L. 2016. A victory in France in the struggle against racial bias in policing. Open Justice Initiative. [Nov. 14, https://www.justiceinitiative.org/voices/victory-france-struggleagainst-racial-bias-policing.]

Hollo, L. and Neild, R. 2012. Challenging police profiling in France. Open Justice Initiative [11 April, https://www.justiceinitiative.org/voices/challenging-police-profiling-france.]

Incyian, E. 2009. Contrôles au faciès: la réponse de la police. Mediapart, 4 juillet. 
Jobard, F. 2006. Police, justice et discriminations raciales. Pp. 211-229 in D. Fassin et E. Fassin (Dirs) De la question sociale à la question raciale? Paris: La Découverte.

Jobard, F., Lévy, R., Lamberth, J., Névanen, S. and Wiles-Portier, E. 2012. Measuring appearance-based discrimination: An analysis of identity checks in Paris. Population 67: 349375.

Jobard, F. et Lévy, R. 2010. Identity Checks in Paris. Penal Issues, January.

Jobard, F. et Lévy, R. 2011. Racial profiling: The Parisian police experience. Canadian Journal of Criminology and Criminal Policy 53: 87-93.

Jounin, N. et al. 2015. Le faciès du contrôle: Contrôles d'identité, apparence et modes de vie des étudiant(e)s en Île-de-France. Déviance et Société 39: 3-29.

Lee, J., 1981. Some structural aspects of police deviance in relation to minority groups. Pp. 49-82 in C. Shearing (ed) Organizational Police Deviance: Its Structure and Control. Scarborough: Butterworth.

Maillard, J. de and Mouhanna, C. 2016. Governing the police by numbers: The French experience. Pp. 273-298 in T. Delpeuch and J. Ross (eds) Comparing the Democratic Governance of Police Intelligence: New Models of Participation and Expertise in the United States and Europe. Cheltenham: Edward Elgar.

Maillard J. de, et Zagrodzki M. 2017. Styles de police et légitimité policière. La question des contrôles. Droit et Société 97: 485-501.

Maillard, J. de, Hunold, D., Roché, S., and Oberwittler, D. 2018. Different styles of policing: Discretionary power in street controls by the public police in France and Germany. Policing \& Society 28: 175-188.

Marc, A. 2016. Rapport fait au nom de la Commission des lois n598. Paris: Sénat.

Napoli, P. 2003. Naissance de la police modern: Pouvoir, normes, société. Paris: La Découverte.

Oberwittler, D. and Roché S. 2018. Ethnic disparities in police-initiated contacts of adolescents and attitudes towards the police in France and Germany. Pp. 73-107 in D. Oberwittler and S. Roché (eds.) Police-citizen relations across the world: Comparing sources and contexts of trust and legitimacy. Abingdon: Routledge.

Paulhamus, M, Kane, R., Piquero, A. 2010. State of the science in racial profiling research: Substantive and methodological considerations. Pp. 239-258 in S. Rice and M. White (eds) Race, Ethnicity, and Policing: New and essential Readings. New York: New York University Press.

Peaucellier S., Jobard F., Lévy R., Spilka S. 2016. Identity Checks and Youthful Parisians: Analysis of the Paris Section of the 2010 ESCAPAD Survey. Penal Issues. 29 (2): 1-4. 
Piazza, P. and Laniel, L. 2008. The INES identity card and the politics of national identity assignment in France. Pp. 198-216 in C. Bennett, C. and D. Lyon (eds.) Playing the Identity Card: Surveillance, Security and Identification in Global Perspective. London: Routledge.

Porter, T. 1995. Trust in numbers: The pursuit of objectivity in science and public life. Princeton: Princeton University Press.

Quinton P. 2015. Race disproportionality and officer decision-making. Pp. 57-7 in R. Delsol and M. Shiner (eds.) Stop and search: The anatomy of a police power. Basingstoke: Palgrave.

Satzwich, V. and Shaffir, W. 2009. Racism versus professionalism: Claims and counterclaims about racial profiling. Canadian Journal of Criminology and Criminal Justice 51: 199-226.

Sayare, S. 2013. France: Court Throws Out Cases Claiming Racial Profiling by Police. New York Times, Oct. 3, Section A, p. 9.

De Schutter, O. and Ringelheim, J. 2008. Ethnic profiling. A rising challenge for European human rights law. The Modern Law Review 71: 358-384.

Sénécat, A. 2016. Oui, le port du matricule est obligatoire pour les policiers et les gendarmes Le Monde, 3 juin.

Skogan, W. 2018. Stop-and-frisk and trust in police in Chicago. Pp. 247-265 in D.

Oberwittler and S. Roché, S. (eds) Police-citizen relations across the world: Comparing sources and contexts of trust and legitimacy. Abingdon: Routledge.

Skolnick, J. 1966. Justice without trial: Law enforcement in democratic society. New York: Wiley.

Terrasse, M. 2019. Dimensions of belongings: Relationships between police identity checks and national identity. Journal of Ethnic and Migration Studies (DOI: 10.1080/1369183X.2019.1578202) 1-22.

Van Maanen, J. 1978. The Asshole. Pp. 221-237 in P. Manning and J. Van Maanen (eds.) Policing: A view from the street. New York: Random House.

Waddington, P., Stenson, K., Don, D. 2004. In proportion: race, and police stop and search. British Journal of Criminology 44: 889-914. 
